\title{
Branchiogén ciszta elöfordulása szokatlan életkorban, ritka lokalizációban
}

\author{
Esetismertetés
}

\author{
DR. HORVÁTH DÓRA, DR. REDL PÁL, DR. HEGEDÜS CSABA
}

\begin{abstract}
A branchiogén anomáliák a veleszületett fejlődési rendellenességek heterogén csoportját képviselik. Branchiogén ciszták leggyakrabban a második kopoltyúív rendellenességeiből származnak. Jellemzően felnőtt korban, felső légúti fertőzést követően alakulnak ki puha duzzanat formájában a musculus sternocleidomastoideus elülső széle mentén, általában annak felső harmadában; de a nyakon bárhol előfordulhatnak a branchialis fistula lefutása mentén a supraclavicularis régiótól a fossa tonsillarisig. Az epipharyngeális lokalizáció ritka. A szerzők egy héthónapos csecsemő gastrointestinalis vírusinfekciója kapcsán végzett gyermekgyógyászati vizsgálat során észlelt szokatlan lokalizációjú, epipharyngeális branchiogén ciszta diagnosztikáját és mútéti eltávolítását mutatják be, a kórkép irodalmi áttekintésével.
\end{abstract}

Kulcsszavak: branchiogén, ciszta, gyermekkor, nyaki duzzanat, epipharynx

\section{Bevezetés}

A branchiogén anomáliáknak jelentős szerepe van a gyermekkori, fej-nyaki régióban előforduló terimék differenciál diagnózisában. A fejlődési rendellenességek közül a második leggyakoribbak [7] és a gyermekkori nyaki duzzanatok 17-30\%-áért felelősek [2, 7, 14, 12]. A veleszületett fejlődési rendellenességek heterogén csoportját képviselik, melyek a branchiogén apparátus maradványaiból származnak. Irodalmi adatok szerint a második garatívből fejlődő elváltozások az esetek 95\%-át teszik ki [2, 6, 15]; előfordulásuk az epipharynxban viszont irodalmi ritkaságnak számít.

A fej és a nyak fejlődésének jellegzetes alakzatai a garatívek vagy kopoltyúívek, melyek a negyedik embrionális hét során jelennek meg. A garatívek váza mesodermából áll, külső felszínüket ectodermális garatbarázdák, belső felszínüket pedig endodermális garattasakok választják el [13]. A branchiogén anomáliák a négy fő garatív és a hozzájuk tartozó barázdák és tasakok maradványaiból fejlődnek, melyek regressziója normálisan bekövetkezik az embriogenezis során. Az eltérések klinikailag sinus, fistula vagy ciszta formájában manifesztálódhatnak [10]. Annak ellenére, hogy már születéskor jelen vannak, a legtöbb eltérést csak későbbi életkorban ismerik fel [12]. A branchiogén fistulák és sinusok főként gyermekkorban kerülnek felismerésre, a ciszták pedig főként felnőttkorban [7]. Nyaki ciszták leggyakrabban a második kopoltyúív rendellenességeiből származnak [6]. Jellemzően felnőttkorban, felső légúti fertőzést követően alakulnak ki puha duzzanat formájában a musculus sternocleidomastoideus elülső széle mentén, annak felső harmadában; de a nyakon bárhol elő- fordulhatnak a branchialis fistula lefutása mentén a supraclavicularis régiótól a fossa tonsillarisig. Kivizsgálásuk során a képalkotó eljárások közül a CT és az MR ajánlott, illetve aspirációs cytológiai mintavétel is szóba jön. A differenciáldiagnosztika során felmerülő kórképek esetén a ciszta pontos elhelyezkedése meghatározó. Kezelésük sebészi, spontán regressziójukra nem számíthatunk.

Jelen közleményünkben egy 7 hónapos gyermeken diagnosztizált szokatlan lokalizációjú, epipharyngeális branchiogén cisztáról és annak sebészi kezeléséről kívánunk beszámolni a kórkép irodalmi áttekintésével.

\section{Esetismertetés}

Medencevégű fekvés miatt császármetszéssel a 36. gesztációs héten született, 7 hónapos csecsemő gastrointestinalis vírusinfekciója kapcsán végzett gyermekgyógyászati vizsgálat a jobb oldali garatfalon elhelyezkedő duzzanatot tárt fel. Fizikális vizsgálattal az oropharynxba benyúló, kb. 1,5 cm átmérőjű kékes-fehéres, ép nyálkahártyával fedett, folyadék bennékü, imponáló cisztózus terimét észleltünk. Az elváltozás a lágyszájpadot és az uvulát minimálisan diszlokálta az ellenoldal felé. A nyakon kóros nyirokcsomót nem tapintottunk. Pontosabb megítélés céljából MR vizsgálat történt, ami az oropharynxban valamennyi szekvenciával folyadéknak megfelelő jelintenzitású, vékony fallal bíró, beboltosuló képletet írt le.

Ennek legnagyobb vastagsága 10-11 mm, hosszirányú kiterjedése $25 \mathrm{~mm}$ volt; így a légsávot jelentősen beszűkítette. Pontos eredetét a vizsgálat nem tisztáz- 


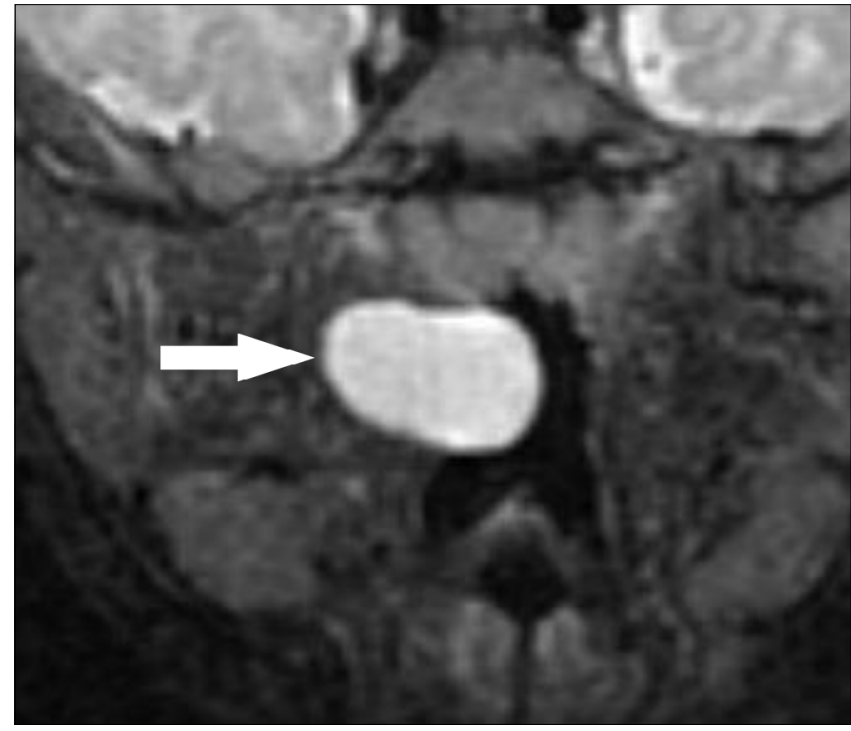

1. ábra: Frontális síkú MR T2 súlyozású felvételen hyperintenz térfoglalás az epipharynxban

ta, de szoros kapcsolatot írtak le a fülkürttel. A ciszta az artéria carotis interna koponyacsontba való belépését elérte, de attól elkülönült. Kontrasztanyag adását követően a vékony cisztafalban látszott csak halmozás, kóros halmozás nélkül.

A pyramiscsonttal, koponyaalappal és a nagyerekkel való viszonyának pontos megítélése céljából $C T$ vizsgálat is történt. Az oropharynxban a jobb oldali laterális garatfalon, a garat lumenét szúkítő 16 mm-es, környezetétől jól elkülönülő fokális elváltozást írtak le, melyet szolidnak és nem cisztózusnak véleményeztek.

A tumortól craniálisan az ékcsont nagy szárnya helyezkedett el, a tumor a koponyabázissal nem volt közvetlen összeköttetésben. Uzuráció a környezetben lévő csontokon nem ábrázolódott. Az elváltozás pontos kiindulását nem állapították meg, dorsolaterális kontúrjánál

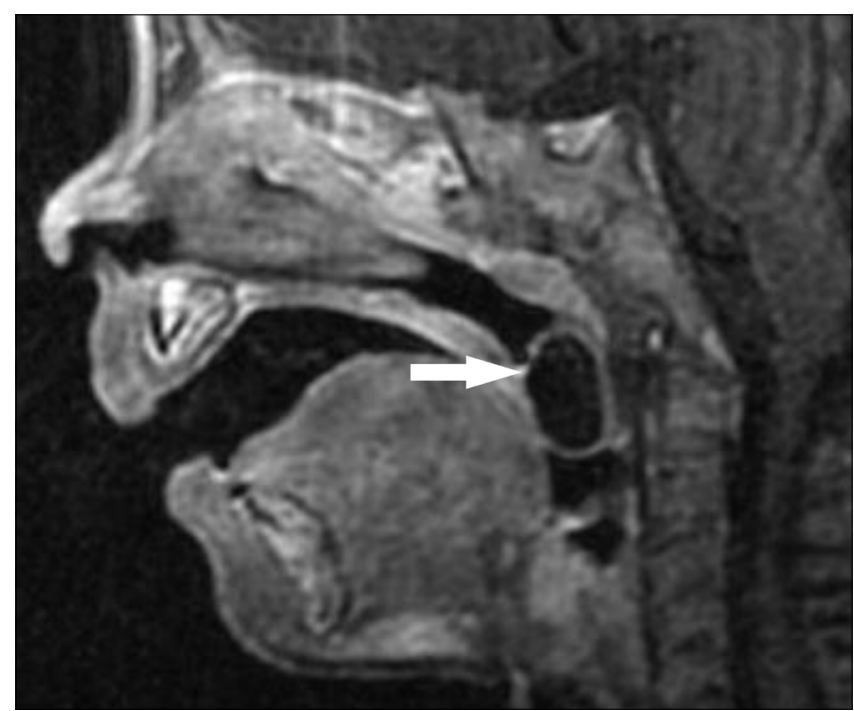

2. ábra: Sagittális síkú MR T1 súlyozású felvételen az orrgaratban ábrázolódó ciszta

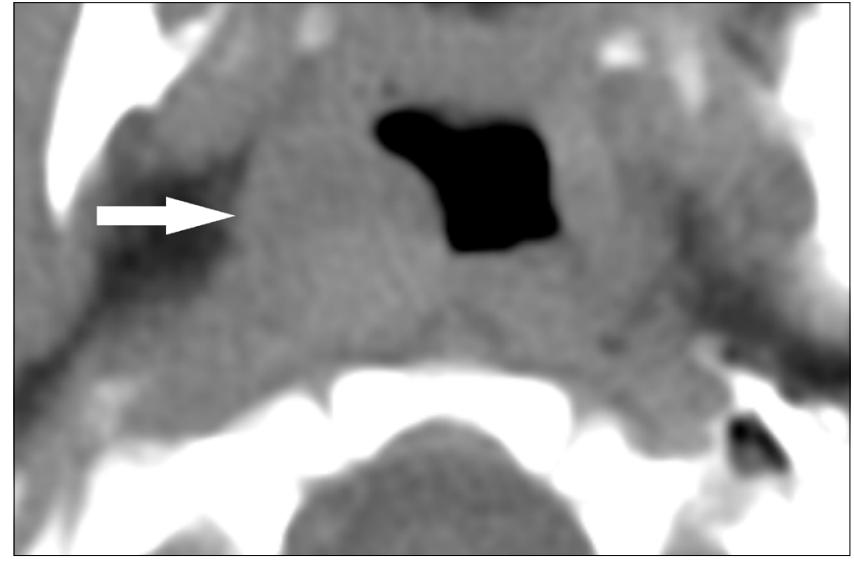

3. ábra: Axiális CT felvételen a garatfalon, a garat lumenét szúkítő szolid képlet

ábrázolódott az artéria carotis interna, melyet leírás szerint a tumor magába foglalt. Aspirációs cytológiai vizsgálat nem történt, tekintettel az ellentmondásos CT és MR leletekre, a nagyerek közelségére, illetve arra, hogy gyermekkorban a branchiogén elváltozások esetén - a vizsgálat következtében létrejövő nehezebben elvégezhető rezekció miatt - a vizsgálatot nem ajánlják [4].

Az egyértelműen cisztózus terime mútéti megoldása mellett döntöttünk, intraorális feltárásból a ciszta teljes eltávolítását terveztük. Általános érzéstelenítésben nasotracheális intubáció mellett a lágyszájpad elkampózását követően látótérbe került az epipharynxból, a fossa supratonsillarisból kiinduló, az oropharynxba benyúló és ott kiszélesedő ciszta.

A garat nyálkahártyáján a ciszta domborulatának megfelelően íves metszést ejtettünk. A vékony cisztafal éles preparálása a garatnyálkahártyától könnyen kivitelezhető volt, azonban a ciszta laterális részén a koponyaalapatlas szögletben környezetével igen szoros kapcsolat mutatkozott, így a ciszta in toto eltávolítása nem volt

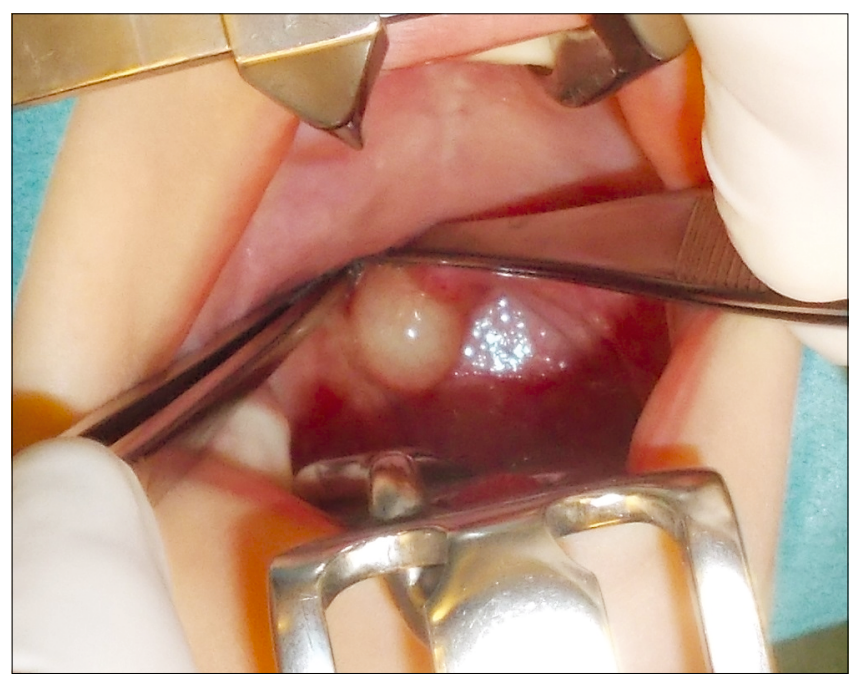

4. ábra: Intraoperatív felvételen a nyelv és a lágyszájpad elkampózását követően az epipharynxból kiinduló, oropharynxba benyúló cisztózus terime 
lehetséges. A ciszta bennéke sárgás mucinosus folyadék volt. Tekintettel a csigolyák, a koponyaalap és az arteria carotis interna közelségére cystostomia elvégzése mellett döntöttünk, a residuális cisztafalat pedig az epipharyngeális nyálkahártyához öltöttük ki.

A visszamaradt üreget jodoformos gézcsíkkal tamponáltuk, melyet az alsó orrjáratban vezettünk ki. Ennek eltávolítására a mútétet követő 3. napon került sor. A postoperatív időszakban antibiotikus és fájdalomcsillapító terápiában részesült (Unasyn, Algopyrin), orális táplálása fokozatosan került bevezetésre. A postoperatív időszak eseménytelenül zajlott: láz, hőemelkedés vagy sebgyógyulási zavar nem jelentkezett. A végleges szövettani eredmény: „Jobb oldali hypopharynxból származó mintában megtartott szöveti szerkezetű kisnyálmirigyek környezetében magas, helyenként többmagsoros, respiratorikus hámmal bélelt tömlőfalrészletek láthatók gócosan chr. lobos beszürődéssel. Egy területben többrétegű, el nem szarusodó laphámfelszínnel. Cysta branchiogenes colli laterális dextri. Malignitásra utaló szöveti jel nincs”. A kontrollvizsgálatok során recidívát nem észleltünk.

\section{Megbeszélés}

A branchiogén struktúrák kialakulása a korai embrionális időszakban elkezdődik, annak negyedik hetében hat pár jól definiált kopoltyúív látható az embrió felszínén, melyeket kívülről ectodermális barázdák, belülről pedig endodermális tasakok választanak el, e kettő között mesoderma található. Ezekből fejlődnek az arc és a nyak struktúrái [10]. A branchiogén anomáliák a négy fő kopoltyúív és a hozzájuk kapcsolódó garatbarázdák és garattasakok maradványaiból alakulnak ki [10]. Az irodalomban több elnevezést használnak leírásukra, közülük néhány fontos definíciót érdemes tisztázni. A branchiogén anomáliák klinikailag ciszta, sinus vagy fistula formájában manifesztálódhatnak. A sinus egy vak tasak, amely ha a garatfal felé nyílik, az a garattasak maradványa, ha pedig a nyak bőre felé, akkor a garatbarázda maradványa. A veleszületett branchiogén fistula tulajdonképpen kommunikáció a két hámfelszín, az ectoderma és az endoderma között. Cisztáról akkor beszélünk, ha nincs összeköttetésük sem a kültakaró, sem a garatfal felé [2]. Kialakulásuk magyarázatára több teóriát említ az irodalom: lehetnek a branchiogén apparátus, a sinus cervicális vagy a ductus thymopharyngeális maradványai. Másrészt parotis eredetűek, hámsejtek implantálódásai a nyaki nyirokcsomókba, nyaki nyirokcsomók cisztikus elfajulásai $[5,6,8,10,11,12]$. A legelfogadottabb ezek közül az, hogy a branchiogén apparátus maradványaiból fejlődnek, melyek regressziója az embriogenezis során nem következik be. A leggyakrabban a második kopoltyúív-barázda komplex érintett, az esetek mintegy 95 százalékában, a maradék nagy részét az első kopoltyúív maradványai teszik ki; a harmadik és a negyedik kopoltyúívből származó fejlődési rendelle-

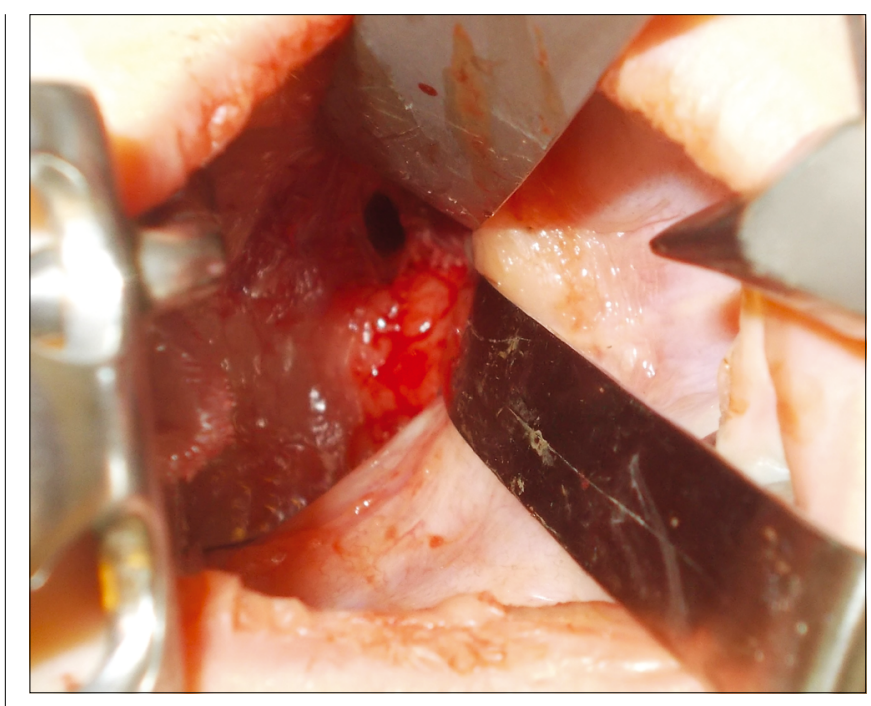

5. ábra: A garat laterális falán elhelyezkedő kiszájaztatott cisztaüreg

nességek kifejezetten ritkák. A branchiogén rendellenességek 20-80\%-át a branchiogén ciszták képviselik, nagy részük a második garatívből ered [6], ezeket Bailey szerint négy csoportra oszthatjuk [1]. Az I. típusba tartoznak a musculus sternocleidomastoideus elülső széle mentén elhelyezkedő felületes ciszták. A II. típusba tartozó ciszták a mély nyaki fascia alatt helyezkednek el, és szoros kapcsolatban állnak a nyaki nagyerekkel és a vagina caroticával. A branchiogén ciszták közül ez a típus a leggyakoribb. A III. típusú ciszták keresztülhaladnak az arteria carotis externa és interna között és elérnek a garatfalig. A IV. típusban a ciszta a garatfal közvetlen közelében található, a nyaki nagyerektől mediálisan helyezkedik el. Ezen beosztás szerint az esetünkben szereplő epipharyngeális ciszta a IV. típusba sorolható.

A ciszták a nyakon bárhol elhelyezkedhetnek a musculus sternocleidomastoideus elülső szélétől a fossa tonsillarisig, amely megfelel a branchiogen nyaki fistula lefutásának. A klasszikus lokalizációjú, a musculus sternocleidomastoideus elülső széle mentén, annak felső harmadában elhelyezkedő ciszták diagnózisa viszonylag egyszerú, a szokatlan lokalizációjú ciszták azonban differenciáldiagnosztikai problémát okozhatnak. Az epipharynxban elhelyezkedő ciszták irodalmi ritkaságnak számítanak. A régióra lokalizálódó terimék differenciál diagnózisánál szóba jövő kórképek: Rathke tasak, pharyngealis bursa (Luschka), Tornwald ciszta, intraadenoid ciszta, retenciós ciszta, abscessus, dermoid ciszta, meningokele, meningoencephalokele, antrochoanalis polyp, teratoma, a sinus sphenoidalis mucokeléje, juvenilis angiofibroma, pleomorph adenoma, lymphoma, kis nyálmirigy tumor, nasopharyngealis carcinoma [5].

A legtöbb epipharyngeális branchiogén ciszta kis méretű és tünetmentes, de okozhat orrdugulást, horkolást, hátsó garatfali váladékcsorgást, fejfájást vagy az Eustach kürt diszfunkcióját. Esetünkben gastrointestinális 
fertőzés miatti rutin gyermekgyógyászati vizsgálat során derült fény az elváltozásra.

A branchiogén ciszták diagnózisa főként az anatómiai lokalizáción és hisztológiai jellegzetességeken alapul. A branchiogén ciszták szövettanilag általában körülhatárolt, fibrotikus tokkal körülvett elváltozások, melyek hámbélése többrétegú laphám vagy respiratorikus hengerhám; alatta intenzív lymphatikus infiltrációval, gyakran kifejlett lymphatikus szövettel [10]. A ciszta bennéke a víztisztától a mucinosusig változhat, és gyakran tartalmaz sejttörmeléket és koleszterinkristályokat.

A korrekt diagnózis elengedhetetlen a kezelés tervezésekor. A branchiogén ciszták kezelésekor a teljes sebészi eltávolításra kell törekedni a normális anatómiai struktúrák megőrzése mellett. Teljes sebészi eltávolítás esetén a kiújulás ritkán fordul elő, azonban nem megfelelő sebészi terápia esetén magas kiújulási rátával kell számolni [2]. Klasszikus lokalizációjú nyaki ciszták esetén aspirációs cytológiai vizsgálat a diagnózis felállításában segítséget nyújthat, majd a teljes sebészi eltávolítás ajánlott, legtöbbször nyaki feltárásból. A konvencionális széles nyaki metszésből kivitelezett eljárás mellett endoszkóppal végzett eltávolítást is említ az irodalom [3, 4]. Szokatlan lokalizációjú ciszták esetén - beleértve az epipharyngeális cisztákat is - CT és MR vizsgálat készítése javasolt a környező anatómiai képletekhez való viszony megítélésére, és a megfelelő sebészi feltárás megtervezésére. A carotis hüvelytöl mediálisan elhelyezkedő ciszták eltávolítása orális feltárásból könnyebben kivitelezhető [9]. Epipharyngeális ciszták esetében is törekedni kell a teljes sebészi eltávolításra, azonban ha ez nem lehetséges, marsupializáció elvégzését ajánlja az irodalom. Orális feltárásból a marsupializáció egyszerü, biztonságos eljárás, amely kevés szövődménnyel jár. Az orális feltárás adja a legjobb kozmetikai eredményt, ami különösen fiatal betegek esetén fontos. Rendszeres kontrollvizsgálatok szüksé- gesek. Nyaki cisztózus terimék esetén - még szokatlan lokalizációban is - számolni kell a branchiogén ciszta lehetőségével.

\section{Irodalom}

1. BAILEY H: The clinical aspects of branchial cysts. Br J Surg 1993; 10: 173-182.

2. Bajaj Y, Ifeacho S, Tweedie D, Jephson CG, Albert DM, Cochrane LA ÉS MTSAI: Branchial anomalies in children. Int J Pediatr Otorhinolaryngol 2011; 75, 1020-1023.

3. Chen J, Chen W, Zhang J, He F, Zhu Z, Tang S és mtsal: Endoscope-assisted second branchial cleft cyst resection via an incision along skin line on lateral neck. Eur Arch Otorhinolaryngol 2014; 271, 2789-2793.

4. Chen L, Sun W, Wu P, Zhang S, Xu M, Luo X És mtsal: Endoscopeassisted versus conventional second branchial cleft cyst resection. Surg Endosc 2011; 26: 1397-1402.

5. CHEN PS, LIN YC, LIN YS: Nasopharyngeal branchial cleft cyst. $J$ Chin Med Assoc 2012; 75, 660-662.

6. DaOud SF: Branchial CYST: An often Forgotten Diagnosis. Asian J Surg 2005; 3: 174-178.

7. ERIKCI V, HosGöR M: Management of congenital neck lesions in children. J Plas Recon Aesth Surg 2014; 67 e217-e222.

8. GolledGE J, ElLIS H: The etiology of lateral cervical (branchial) cysts: past and present theories. J Laryngol Otol 1994; 108: 653-659.

9. Houck J: Excision of branchial cysts. Operative technics in Otolaryngology 2005; 16, 213-222.

10. MANDELL DL: Head and neck anomalies related to the branchial apparatus. Otolaryngol Clin North Am 2000; 33, 1309-1329.

11. PaCzona R, Jóri J, CZIGner J: Pharyngeal localizations of branchial cysts. Eur Arch Otorhinolaryngol 1998; 255, 379-381.

12. Prasad SC, Azeez A, Thada ND, Rao P, Bacciu A, Prasad KC: Branchial Anomalies: Diagnosis and Management. Int J Otolaryngol 2014; ID 237015, 9

13. SANDLER TW: Langman Orvosi Embriológia. Medicina Kiadó, Budapest, 1999. 323-341.

14. Schroeder JW, Mohyuddin N JR, Maddalozzo J: Branchial anomalies in the pediatric population. Otolaryngol Head Neck Surg 2007; 137: 289-295.

15. WALDHAUSEN JHT: Branchial cleft and arch anomalies in children. Semin Pediatr Surg 2006; 15: 64-69.

\section{Horváth D, Redl P, Hegedüs Cs}

\section{Branchiogen cyst at unusual age and in rare localisation A case report}

Branchiogen anomalies represent a heterogeneous group of developmental abnormalities, they arise from incomplete obliteration of branchial clefts and pouches during embriogenesis. Clinically they can present as a cyst, fistula or sinus. Second cleft lesions account for $95 \%$ of the branchial anomalies. Second branchial cleft cysts are usually located in the neck, along the anterior border of the stenocleidomastoid muscle, but they can be anywhere along the course of the second branchial fistula from the tonsillar fossa to the supraclavicular region. Their presence in the nasopharynx is extremely rare. Ultrasound, computed tomography (CT) or magnetic resonance imaging is recommended for diagnosis. Definitive treatment is surgical excision, these lesions do not regress spontaneously and often result recurrent infections.

A 7 month old infant applied to a pediatrician with gastrointestinal viral infection. During examination a cystic mass was discovered in the right lateral nasopharyngeal wall, the lesion extended to the oropharynx. Marsupialisation was performed via transoral approach. In case of cystic lesion in the lateral epipharynx, branchial cleft cyst should be considered in the differential diagnosis.

Keywords: branchiogen anomalies, second branchial cleft cyst, congenital neck mass, epipharynx, marsupialization 